Portland State University

PDXScholar

\title{
Adverse Effects of Mercury and Some Management Options to Reduce Dental Amalgam Waste
}

\author{
Marta Szabatin \\ Portland State University
}

Follow this and additional works at: https://pdxscholar.library.pdx.edu/honorstheses

\section{Let us know how access to this document benefits you.}

\section{Recommended Citation}

Szabatin, Marta, "Adverse Effects of Mercury and Some Management Options to Reduce Dental Amalgam Waste" (2016). University Honors Theses. Paper 278.

https://doi.org/10.15760/honors.315

This Thesis is brought to you for free and open access. It has been accepted for inclusion in University Honors Theses by an authorized administrator of PDXScholar. Please contact us if we can make this document more accessible: pdxscholar@pdx.edu. 


\title{
Adverse Effects of Mercury and Some Management Options to Reduce \\ Dental Amalgam Waste
}

\author{
by \\ Marta Szabatin \\ An undergraduate honors thesis submitted in partial fulfillment of the \\ requirements for the degree of \\ Bachelor of Science \\ in \\ University Honors \\ and \\ Environmental Science and Management \\ Thesis Advisor: \\ Dr. Eugene Foster \\ Portland State University \\ 2016 Spring Term
}




\section{Table of Contents}

List of Tables and Figures 3

Abstract 4

Research Question 4

Acknowledgement .5

1. Introduction .6

2. Methodology 10

3. Literature Review .11

3.1 Sources and forms of mercury .11

3.2 Environmental effects of mercury 15

3.3 Human health impacts of mercury 21

3.4 Management options to reduce mercury-containing dental waste .24

4. Conclusions .34

References .36 


\section{LIST OF FIGURES AND TABLES}

Figure 1: The Mercury Cycle in the Florida Everglade

Source: USGS, 2013

Figure 2. Largest mercury emitters at global level

Source: United Nations Environmental Programme, Global Mercury Assessment, 2013

Figure 3. Main sources of mercury and their contribution to total environmental mercury in the Willamette Basin

Source: Oregon Department of Environmental Quality, Willamette Basin Mercury TMDL, 2007

Figure 4. General scheme of mercury transformations in the ocean

Source: Batrakova, N., Travnikov, O., Rozovskya, O., Chemical and

physical transformations of mercury in the ocean: a review. Ocean

Science, 10: 1047-1063

Figure 5: Mercury biomagnifies through the food web

Source: ttp://www.trueworldfoods.com/ faq/how-much-mercury-is-safe.php

Figure 6: Chair side traps

Source: Marta Szabatin, MHCC Dental Hygiene Dept. 2016

Figure 7. Handling empty amalgam capsules at MHCC Dental Hygiene Department Source: Marta Szabatin, 2016

Table 1. Best Management Practices for Amalgam Waste

Source: American Dental Association, Best Management Practices for Amalgam Waste, 2007

Table 2. Comparison of Dental Amalgam Capturing Devices

Source: Burkhart Dental, University of Massachusetts, California Dental Association, Oral Health 


\section{ABSTRACT}

Mercury is a persistent, toxic pollutant and at elevated levels can cause serious environmental harm to aquatic life, wildlife, and humans. Mercury from anthropogenic sources continues to be a significant risk to human health causing regulatory agencies to address this issue. The purpose of this study is to review the sources, forms and adverse effects of mercury, and identify the tools regulating mercury-containing dental waste management, and the advantages and disadvantages of various management practices that help to minimize mercury releases into municipal sewage system and into waterbodies. Dental facilities are significant mercury dischargers to wastewater treatment facilities and dental clinics have become a priority for regulatory initiatives and strong mercury minimization efforts in recent years. This study evaluates the management practices, appropriate tools and techniques, and proper recycling and disposal methods that are important for mercury minimization efforts at dental offices.

\section{RESEARCH QUESTION}

What potential hazards are posed to human health and the environment by mercury exposure, and what management practices can help to reduce the risks presented by mercury-containing dental waste generated at dental clinics and dental schools? 


\section{ACKNOWLEDGEMENT}

Foremost, I would like to express my sincere gratitude to my Thesis Advisor Dr. Eugene Foster for his immense help with my Honors Thesis. His great knowledge, guidance, and useful comments have greatly contributed to competing a quality work and being able to finish my Thesis on time. Also, many thanks to him for his help with networking, for the excellent supporting materials, relevant books and articles, for his continuous support and his understanding of my challenges with balancing between studies, work, and family.

I also would like to say thanks to Dr. David Wolf, my Advisor at the University Honors College, for his encouragement, teaching me how to improve my writing skills, the writing schedule keeping me on track, and for always believing in me.

Besides my professors, I owe a debt of gratitude to my Advisor Dr. Joseph Maser at the Environmental Sciences Department, for his support, making me believe that I can complete my Bachelor's studies, and for paving my way towards this goal.

I also want to say thanks for the Mt. Hood Community College Dental Hygiene Department and the Clean Water Services for providing me with critical information on the amalgam capturing processes, and for their absolutely helpful attitude.

I want to say a heartfelt thank you for my parents who taught me to be a responsible person, finish what I started, strive for perfection, and be open-minded, curious, and persistent. Without these traits, I would not be able to succeed.

Last but not least, I want to say a big thank you for my two wonderful children, Zoltan and Eddie, for patiently listening my endless practice presentations in our living room, and for understanding that that studying takes us towards a better future. 


\section{INTRODUCTION}

The face of our planet Earth has been continuously changing. This change is caused in part by natural processes for example tectonic movements, volcanic and hydrothermal vent activities, and other natural disasters. The other main source of environmental changes is anthropogenic activities. Human impacts have been posing significant threat to the environment, especially since the eighteenth century when the industrial revolution has begun (Pellow and Brehm, 2013). Ever since, degrading environmental quality due to anthropogenic activities is a global phenomenon (Hoekstra and Wiedman, 2014). Our air, waters, and soils have been continuously exposed to harmful chemicals, thereby decreasing the chances of living organisms, including humans, to live a healthy life, what is more, to survive.

Heavy metals have a distinctive role in environmental pollution because these contaminants have been released from multiple industrial, agricultural, pharmaceutical and domestic sources, and their effects on the environment can be devastating if present in elevated concentrations (Akoto et al, 2014).

Mercury is a heavy metal that naturally occurs, mostly in the form of cinnabar deposits, or as a result of weathering of rocks, geothermal and volcanic activities (Watras and Huckabee, 1994, Hyman, 2004). Although natural sources have been recognized as sources of mercury, studies have shown that mercury deposition has increased by thirty times in the last hundred years and $70 \%$ of this is a result of human activities (Kohl and Hyman, 2004). This high and increasing rate of human contribution to environmental mercury levels could be causing environmental harm and risk to 
human health and becomes important to take actions to reduce anthropogenic mercury emissions to reduce this risk.

Mercury is a persistent, toxic pollutant that has bioaccumulative properties. Mercury discharged into the environment can be found in the air, soils, and water, causing potential exposure and risk to organisms in nearly all kinds of habitats. In the environment, elemental mercury is readily converted into bioavailable, highly toxic organic mercury compounds such as methyl mercury and organic mercury salts (Watras and Huckabee, 1994, Ji, 2011). Toxic mercury compounds accumulate in organisms and biomagnify through the food web, causing serious damages to ecosystems (Atwell et al, 1998).

Multiple studies have shown that mercury accumulation in aquatic organisms has been occurring throughout the United States (Ji, 2011, Hope et al, 2009). These higher levels of biomagnified mercury can pose serious risk to organisms. Both long-term mercury monitoring and recent studies in the Pacific Northwest have shown that mercury levels in the Willamette River have been consistently high, resulting in frequent health advisories limiting fish consumption in recent years (Oregon Health Authority, 2016). Mercury emissions originate from industrial, commercial, and residential sources, with coal combustion, chlorine and cement production, and mining activities as the most significant sources (Eisler, 2013, Watras and Huckabee 1994, OR DEQ, 2006).

Dental offices are relatively small sources of mercury as compared to other sources but are well recognized contributors to environmental mercury levels. While the mercury emissions from dental offices are relatively small, these facilities are significant 
mercury dischargers to municipal wastewater system. In their study, Singh et al. (2014) stated that "dental clinics are playing a major role in mercury discharge." Based on recent studies by Clean Water Services, OR, about $50 \%$ of the mercury in Clean Water Services Publicly Owned Treatment Works (POTWs) come from dental clinics. Studies have shown that municipal wastewater treatment facilities contribute approximately 2.7 \% to the mercury load to U.S. waterbodies (DEQ, 2006), and about $50 \%$ of this mercury comes from dental offices (DEQ, 2006, CWS, 2015). Therefore, dental clinics have become a priority for regulatory initiatives and strong mercury minimization efforts in recent years because of regulatory efforts to reduce mercury releases to waterbodies.

Mercury-containing dental amalgam has been used for more than 150 years in restorative dentistry (Rathore et al, 2012) and continues to be used today, despite the toxicity of its main ingredient, elemental mercury, which is known to be harmful to humans and the environment even at low concentrations (Chin et al, 2000). The use of dental amalgam has been controversial because it has multiple benefits and significant risks. The American Food and Drug Administration (FDA, 2014) has evaluated those risks and benefits and stated that dental amalgam has multiple advantages; mercurycontaining amalgam alloys are long-lasting and strong, they are the least expensive solution among the different types of filling materials. At the same time, FDA acknowledges that evidence was found that mercury pose multiple adverse effects: it can cause serious damage to the brain and kidney, and multiple different abnormalities to the nervous system, especially for young children (FDA, 2014, Jackson et al, 2004).

In addition to the direct effects of the use of dental amalgam in dentistry to human health, the release of uncontrolled or improperly managed amalgam waste can 
pose additional hazards to human and environmental health. Studies by Chin et al (2000) show that the contribution from dental amalgam to the total terrestrial mercury contamination is small compared to industrial pollution or pollution from combustion of fossil fuels. However, other studies (Condrin, 2000, Hiltz, 2007) show that mercurycontaining amalgam waste generated in dental clinics present significant risk to organisms, including humans, due to its multiple adverse effects on brain, kidney, liver, and other physiological functions. Some studies discuss a growing concern that the amount of dental mercury in the environment has been alarmingly increasing in the past decade, especially in municipal wastewaters (Condrin, 2000).

However, there has been agreement that mercury-containing dental waste should be prevented from entering the environment, and the use of safe management practices, appropriate tools and techniques, and proper recycling and disposal methods are key in reducing the risks from mercury exposure (Baskhar, 2012, Jokstad et al., 2006, Trip, 2001, McManus, 2003). Risk communication about mercury to the dental offices could be important for adoption of BMPs by dental offices and reducing mercury releases to the sewage treatment plants.

The purpose of this study is to review the main sources and forms of mercury, the effects and risks from mercury exposure to human health and the environment, and evaluate the best management practices that can help to reduce the release of mercury-containing dental waste generated at dental schools and offices which will help to improve mercury minimization efforts. 


\section{METHODOLOGY}

A comprehensive review of relevant, current, peer-reviewed literature was done from the areas of human and ecological toxicology, general dentistry, and public health to provide a general idea about main mercury sources, the forms and transport of mercury in the environment, mercury releases from dental facilities, and management options to handle mercury-containing dental waste. Relevant environmental laws, and rules by dental organizations were reviewed for requirements and best management practices, technologies and strategies were evaluated that are available for dental clinics and schools for mercury minimization efforts.

In addition to the literature review, site visits were completed by the author at Mt. Hood Community College Dental Hygiene Department, and two Clean Water Services POTWs to obtain information on mercury management practices, waste management options and regulatory requirements. These site visits provided valuable practical information and data on mercury emissions from different sources, including dental facilities, and provided an opportunity to observe the types of dental capturing devices that prevent mercury particles from entering into the sewage system. These sources of information were used for qualitative evaluations of advantages and disadvantages of dental amalgam management reduction technologies available to dental offices and schools. 


\section{LITERATURE REVIEW}

\subsection{Sources and levels of mercury in the environment}

Mercury is a naturally occurring element, found in multiple forms and at locations in the environment. The most significant natural sources of mercury are rocks, soils, volcanic eruptions, geothermal activities, emissions from the ocean, and cinnabar deposits (Watras and Huckabee, 1994). Common forms of mercury in the environment are elemental mercury, mercury salts, organic mercury compounds, and mercuric sulfide, mainly in cinnabar deposits (Boening, 2000). Among these mercury compounds, the organic compounds, methyl mercury in particular, present the greatest risk to humans and the environment, because these compounds are readily accumulated and biomagnified, and are very toxic at low concentrations.

Globally, atmospheric circulation is the most significant factor in mercury transport (Lindqvist and Rhode, 2010). Elemental mercury found in the environment and also, from certain anthropogenic sources is easily vaporized into the atmosphere and transported great distances via atmospheric circulation. Mercury can then be deposited in the soil and water bodies, converted into other forms of mercury, and taken up by organisms (Figure 1).

Other mercury transport mechanisms can have a more localized cycle. Mercury from sources that are not significant at a global scale can be significant at the local level because mercury released into the air, soils, and waters, can be accumulated by plants, animals, and humans near where these releases occur. 


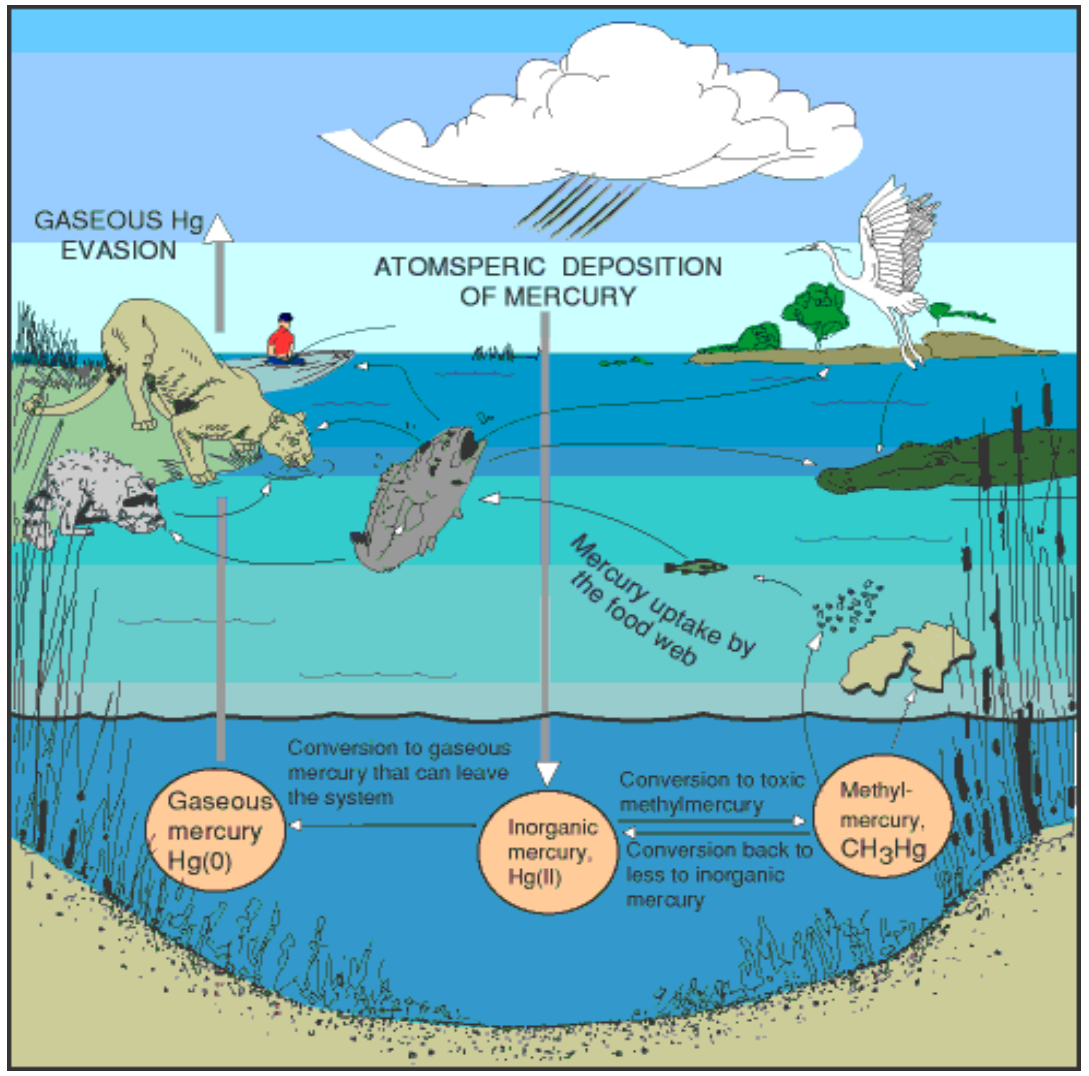

Figure 1: The Mercury Cycle in the Florida Everglade Source: USGS

Mercury has multiple uses, the major ones are gold mining, cement and chlorine production, electrical equipment, paint and wood pulping industries; these latter three industries use more than half (55\%) of the total mercury consumption in the United States (Boening, 2000). However, according to the Global Mercury Assessment by the United Nations Environment Programme (2013), worldwide the largest sources of environmental mercury are gold mining, coal combustion, and metal and cement production (Figure 2). 


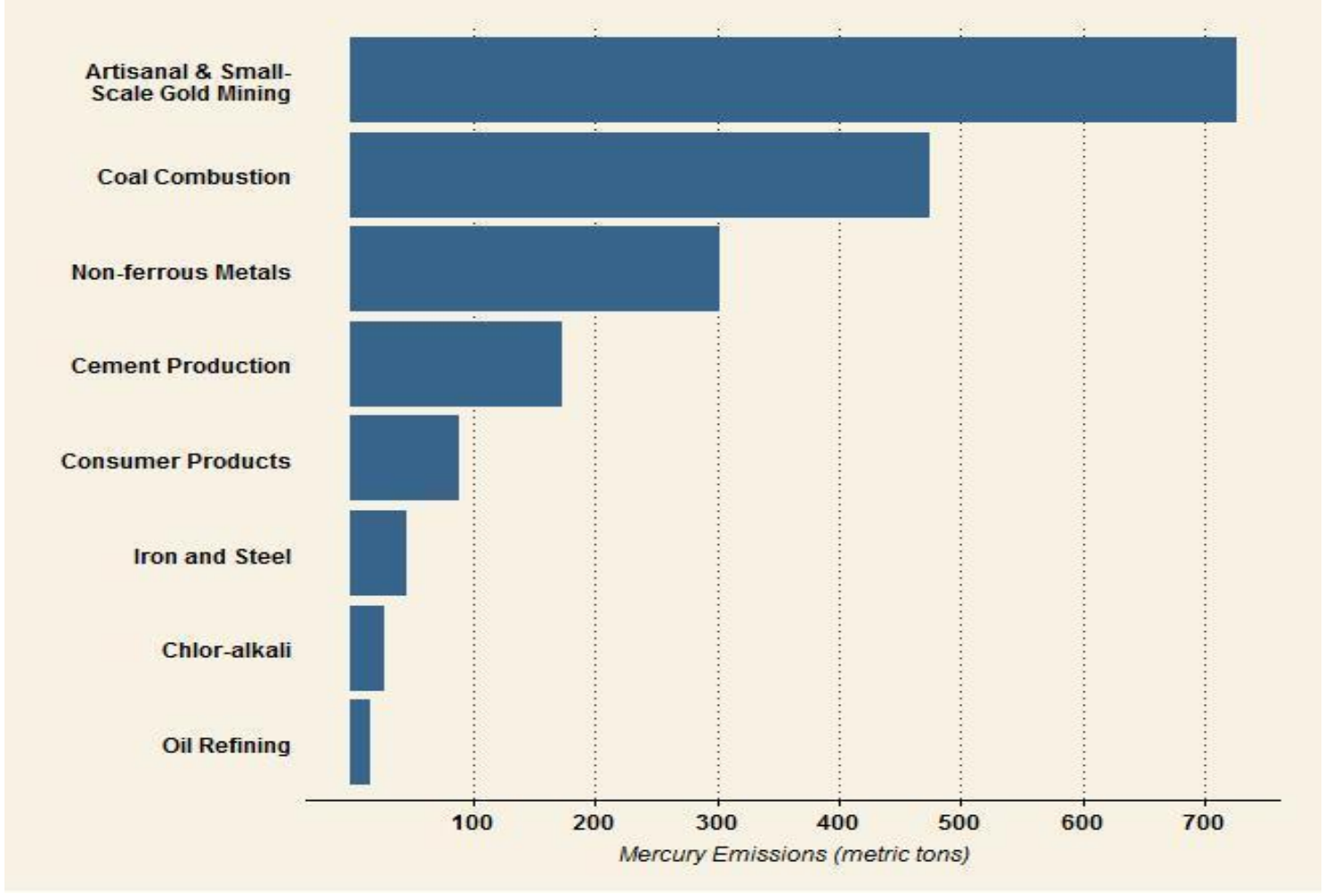

Figure 2. Largest mercury emitters at global level

Source: United Nations Environmental Programme, Global Mercury Assessment, 2013

Mercury also has military and healthcare applications, and it is also used in batteries, medicines, and restorative dentistry (Boening, 2000). In addition to these sources, residential sources also contribute to environmental mercury which comes from human waste, laundry greywater, and certain consumer products. The main mercury sources of total mercury in the Willamette River Basin is a fairly good representation of the distribution of mercury sources at national level (Figure 3). The graph is a result of a basin-wide monitoring program and literature review conducted by Oregon Department of Environmental Quality (DEQ 2006). 


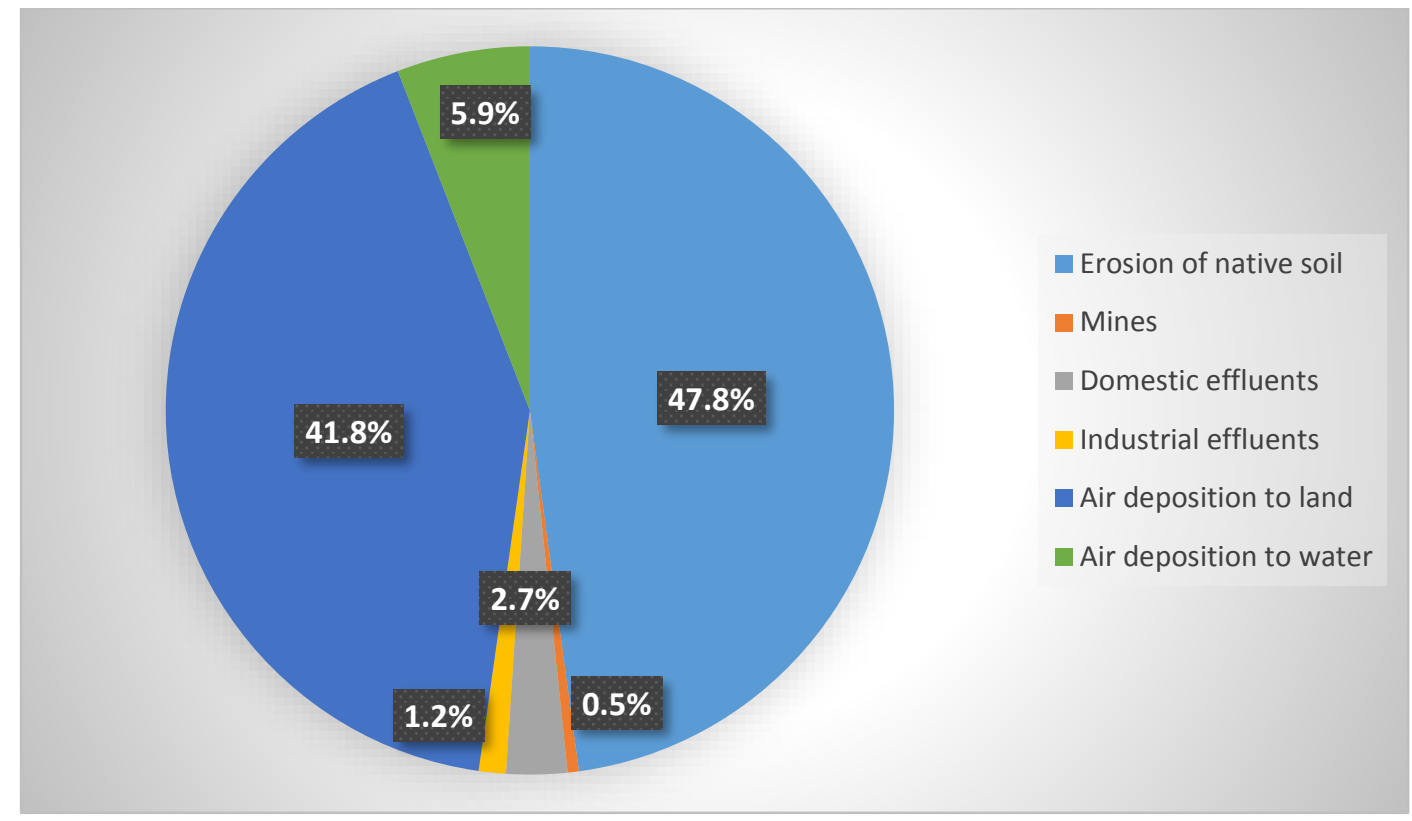

Figure 3. Main sources of mercury and their contribution to total environmental mercury in the Willamette Basin

Source: Oregon Department of Environmental Quality, Willamette Basin Mercury TMDL, 2007

The releases of mercury from dentistry has been receiving attention in recent years. Studies (Chin, 2000, Condrin et al, 2004) found that dentistry contributed only a small fraction - less than $1 \%$ - to total mercury releases and recent studies (Baghele, 2013 , more reference) estimate these releases at 3-4\%. In Oregon, the total this rate is about $1.5 \%$ (DEQ, 2006). However, dental amalgam waste can be a significant source of mercury to sewer systems and POTWs. When old fillings are replaced by new ones, the old filling material is often flushed down through the chair-side drains. Some of these solid particles settle in the local sewer system, but some of them are carried to POTWs. The majority of the solid mercury is filtered out from the waste water and about only $10 \%$ remains in the effluent. This residual mercury usually passes through the additional treatment processes and end up in the biosolids or the sewage sludges. 
A watershed-scale analysis of the Willamette Basin found that the majority of the mercury in the Willamette is from non-point sources: soil erosion and atmospheric deposition, and roughly $2.7 \%$ of the total environmental mercury is from POTWs of which approximately $50 \%$ come from dental clinics, and the amount of mercury from dental offices nationally is approximately 4.4 tons/year (DEQ 2006, Hope, 2006, EPA Dental Effluent Guidelines, 2016). These rates indicate that dental clinics and schools release very small amount of mercury to the environment compared to other anthropogenic sources. However, dental clinics and schools can be significant sources to POTWs and the number of these facilities is increasing requiring programs to ensure that mercury releases from these facilities are under control. Controlling and reducing mercury releases from dental offices to POTWs discharging in the Willamette Basin can help POTWs to meet their regulatory requirements. The Willamette Mercury TMDL requires a $27 \%$ reduction in mercury releases from all source categories, including TMDLs.

\subsection{Environmental Effects of Mercury}

A number of studies have shown that mercury poses serious threat to biotic systems when released into the environment. While mercury in its elemental form is less toxic than methyl mercury (Watras and Huckabee, 1994), elemental mercury and other inorganic mercury compounds in the environment readily undergo methylation (Renzoni et al, 1997) and form the very toxic methyl mercury (Figure 4). In their studies, Eisler (1987), Hiltz (2007), and Hyman (2004) showed that once inorganic mercury from 
dental uses is released into the environment, it is readily available to be converted to methyl mercury.

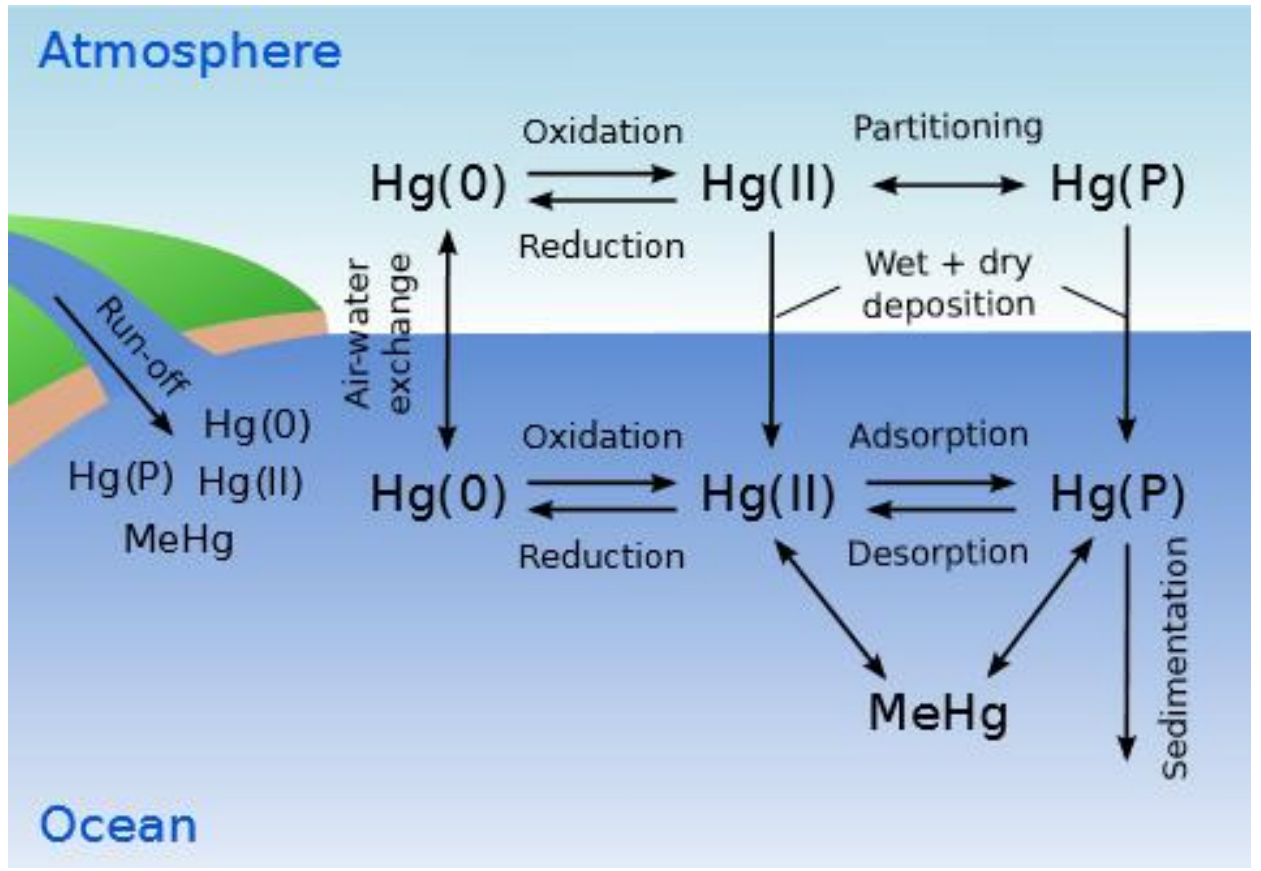

Figure 4. General scheme of mercury transformations in the ocean Source: Batrakova, N., Travnikov, O., Rozovskya, O., Chemical and physical transformations of mercury in the ocean: a review. Ocean Science, 10: 1047-1063

Methylation of mercury is influenced by water quality characteristics such as temperature, redox potential, organic matter content, and also, anaerobic conditions play a role in this process (Batrakova et al, 2014, Boszke et al, 2002). Methylation takes place mainly as a result of natural processes, involving different types of microorganisms, mainly bacteria that are or are associated with sulfate reducing bacteria (Compeau and Bartha, 1985), but other processes, for instance chemical reactions in soils and photochemical processes (Tong, 2012) possibly can also cause methylation of mercury. 


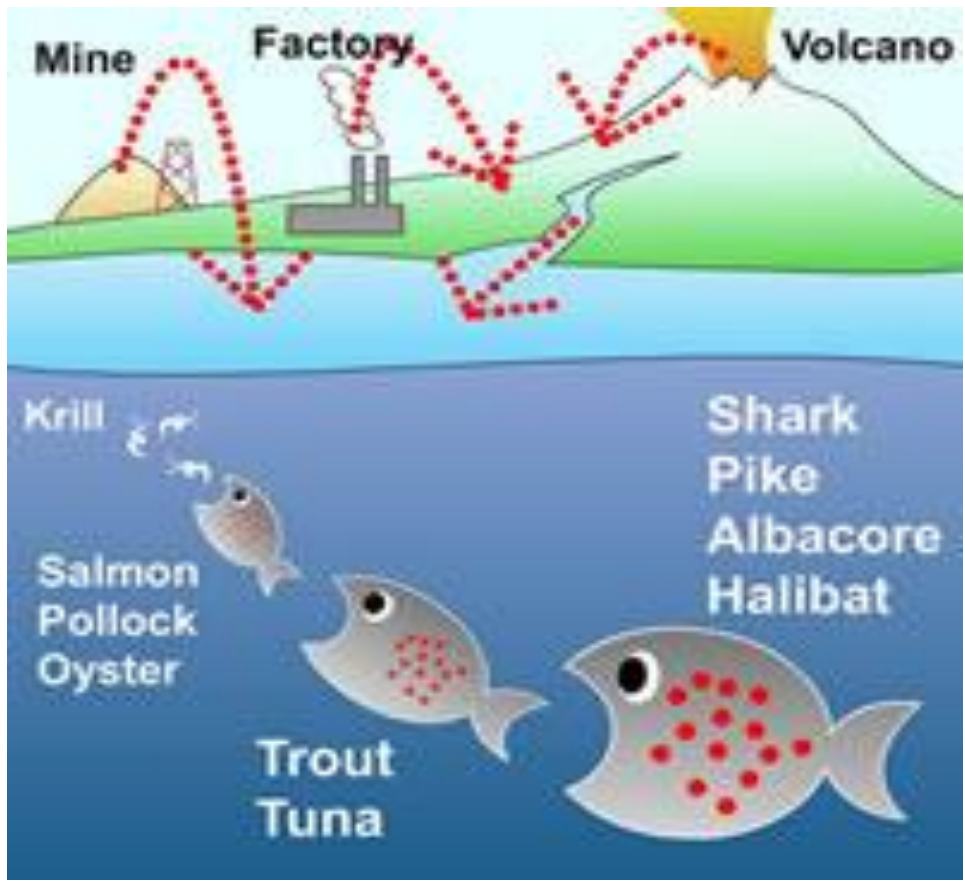

Figure 5: Mercury biomagnifies through the food web Source: ttp://www.trueworldfoods.com/ faq/how-much-mercuryis-safe.php

Studies by Eisler (1987) and Sunderland and Selin (2012) emphasize that the bioaccumulation of mercury in aquatic food chains poses additional risk to humans and higher trophic level organisms. Some studies show that the bioavailability of mercury depends on different physical, chemical, and biological factors such as temperature, phase association, adsorption and sequestration, thermodynamic equilibrium, complexation kinetics, lipid solubility and octanol/water partition coefficients, and trophic interactions (Tchounwou, 2012). In aquatic environments severity of toxicity is dependent on multiple factors such as water temperature, hardness, salinity, and dissolved oxygen concentration. Dietz et al (2012) in their study suggest that mercury may be accountable for a wide variety of physiological, biological, and biochemical abnormalities in fish and birds such as change in enzyme production and activity, 
decreased cardiovascular function, blood parameter changes, immune system deficiencies, impaired kidney functions, and many different behavioral changes.

Mercury can pose serious risk to organisms because low levels of mercury be converted into highly toxic organo-mercury forms of mercury such as methyl mercury and organic mercury salts, that can bio-accumulate in organisms and biomagnifies through food chains (Figure 5).

In birds and mammals, mercury adversely affects reproduction, growth and development, nervous system, and metabolism (Varian-Ramos et al, 2014, Dietz et al, 2012). In addition, mercury in aquatic organisms can also disrupt blood chemistry the ability for osmoregulation, and oxygen exchange. Toxic mercury compounds biomagnify through the food web and can cause serious damage in aquatic and terrestrial ecosystems.

Mercury concentrations in fish tissue increases with age (Sackett et al, 2013). Aquatic organisms readily accumulate mercury and retain it for long period of time, especially if it is an organomercury, eg. methyl mercury (Nordberg et al, 2004). In addition, organomercury is acutely toxic to aquatic microorganisms and invertebrates. Organic mercury compounds 10 - 100 times more toxic than the inorganic forms making bioaccumulated mercury a significant risk to aquatic organisms and organisms that consume them (Varian-Ramos et al, 2014).

Through the food web, fish, birds, mammals and other consumers have been exposed to mercury which bioaccumulates throughout their life. The studies of Dietz et al (2012) found that mercury concentrations have already exceeded the threshold limits 
for several species including polar bears, seals, fish and bird species. And this is not unique to the Arctic environment, other locations worldwide have high mercury levels in the food web.

Studies have shown that piscivorous birds are particularly at risk due to their diet (Varian-Ramos, 2014); however, it seems songbirds are also vulnerable to mercury exposure (Varian-Ramos, 2014, Jackson et al., 2011). The Varian-Ramos study showed that many songbird populations are at risk and many of them suffer population declines due to decreased reproduction and survival from mercury toxicity. VarianRamos and colleagues specifically investigated how the effects differed when the birds were exposed as adult or throughout their lifetime to better understand the exposuretiming affects on the birds' condition. The results supported their hypothesis; environmentally relevant mercury exposure caused reduced reproductive success and survival rates. Reproductive success was reduced at all mercury levels, including the lowest dose (0.3 ppm). This means that adverse effects could be expected at dietary mercury concentrations (below 0.3 ppm). They also found that birds receiving chronic exposure were more vulnerable at lower doses. This finding shows that long-term, low mercury levels in the environment - that commonly occur today at a global scale - are a reasonable concern and need to be addressed. In addition to these studies, others (Hope, 2005, Tchounwou, 2012) have also concluded that mercury presents a serious threat to organisms even at very low concentrations.

There are a limited number of studies on how plants are affected by mercury exposure (Assche, 1990, Azavedo and Rodriguez, 2012). These studies found that plants take up mercury primarily from the soils, mercury can bioaccumulate in their 
tissues, and can cause toxicity. Elevated mercury levels can lead to stress in plants, and as a result, a decrease in root and shoot growth, seed germination and enzyme activities can be inhibited, and tissue damage can also occur. The issue with mercuryaccumulation in plants is that plants are consumed by different herbivorous organisms, bioaccumulates in these organisms and has adverse effects on the organisms at the higher levels of the food chain. Although these studies found that many plants have also been adversely affected by mercury pollution, they also stated that, in general, plants seem to be less vulnerable to mercury toxicity.

Elevated mercury levels in fish have also been a well-known environmental issue in the Pacific Northwest, including the Willamette River Basin, which resulted in frequent health advisories limiting fish consumption in the recent years (Oregon Health Authorities, 2016). Mercury occurs in the Willamette Basin in many different forms, including inorganic and organic mercury compounds. A basin-wide study by the Oregon Department of Environmental Quality indicates that the majority of mercury comes from non-point sources: erosion of native soils and air deposition (Willamette Basin Mercury TMDL, 2006).

Mercury and methyl mercury spatial and seasonal trends in Willamette Basin river water and fish tissue were conducted (Hope and Rubin, 2005). Lowest mercury levels were found in the Middle Fork of the Willamette River, at the farthest upstream sampling location, and mercury levels became consistently higher going downstream. Total mercury levels were generally higher in the high-flow winter seasons while methyl mercury was higher in the low-flow summer months. 
Sediment mercury levels follow a similar pattern; mercury levels were lowest in the Middle Fork that is considered a more pristine area and highest in the Coast Fork (Cottage Grove) where there is historic mining activities and mercury contaminated mine tailings (Park and Curtis, 1997). Mercury levels were the highest in piscivorous (fish-eating) fish and the lowest in invertevorous (invertebrate-eating) fish, reinforcing mercury's bioaccumulative properties throughout the food web (Hope and Rubin, 2005).

\subsection{Human Health Impacts of Mercury}

Humans can be exposed to mercury in many ways. One of the most common way is by taking mercury-containing medications. Another significant exposure route is fish consumption (Davidson et al, 2004). Children and women of child bearing age are particularly sensitive to mercury exposure as methylmercury is able to cross the bloodbrain and the placenta barriers, and selectively attacks the brain cells of the developing brain (Clarkson and Magos, 2006).

The half-life of methyl mercury is approximately 100 days in the human body (for blood and hair) (Yaginuma-Sakurai et al., 2012) causing a slow excretion process which helps to explain the bioaccumulative properties of mercury. Methylmercury persists in the human body, accumulates, and attacks the cells of the brain and other organs.

There are many forms of mercury and these different forms of mercury have differential toxicity. Studies found that inorganic forms of mercury, such as elemental mercury, mercuric and mercurous compounds from industrial sources, and dental 
amalgam release vapors and these vapors if inhaled can cause adverse health effects. Mercury is nonpolar, lipid-soluble, the vapors are easily absorbed by the lungs, then spread through the blood stream, reach the target organ and cross the blood-brain barrier, and cause damages to the central nervous system (Clarkson and Magos, 2006). Symptoms include neuromuscular changes, insomnia, headache, emotional changes (e.g. irritability, nervousness, excessive shyness), and changes in nerve responses. Higher exposures to inorganic mercury can also cause damages to the kidneys and the gastrointestinal tract, and can result in respiratory failure and even death (EPA, 2016).

The cells of the human body have a defensive mechanisms against the inorganic forms of mercury. Theories exist that the development of these defensive mechanisms began when life started forming on Earth in response to the early atmosphere's high concentration of mercury vapors (Watras and Huckabee, 1994). In order to survive, living cells protected themselves from the toxic effects of inorganic mercury using the enzyme catalase and through a series of biochemical processes, mercury is oxidized to divalent mercury which is then trapped in the cells. This ionic form of mercury is then subjected to other defense mechanisms that involves selenium which binds with divalent mercury and forms an insoluble compound that is excreted with feces from the human body (Clarkson and Magos, 2006). In addition to this mechanism, mercury can be excreted from the body via the liver and bile.

While inorganic forms of mercury are a risk to human health, the most significant adverse health effects are from organic mercury compounds, methyl mercury in particular (Clarkson and Magos, 2006). This could be due to the body not having 
effective cellular protection against methyl mercury. Similarly to elemental mercury, methyl mercury was also present in the forming planet, however organisms with complex brain, like primates and humans, were not present at that time so did not develop evolutionary defense against methyl mercury (Watras and Huckabee, 1994). Speculation exist that the developed brain and intricate nervous system of primates, particularly of humans, have not had sufficient time to develop defensive mechanisms. An evidence for this theory is that methyl mercury way less hazardous for lower organisms with simpler nervous system.

Among organic mercury compounds, ethyl and methyl mercury are the most common, and for the humans methyl mercury poses the greatest hazard in terms of toxicity. Methyl mercury selectively attacks the central nervous system and the evolutionary more advanced parts of the brain such as the cortical areas (Clarkson and Magos, 2006). Methyl mercury readily crosses the blood-brain barriers and also the placental barrier and easily reaches the fetal brain. While the mechanisms of mobility of methylmercury is poorly understood, studies have already confirmed that this toxic chemical creates water-soluble compounds with certain amino acids and proteins which relatively easily penetrates through the cell walls (Clarkson and Magos, 2006).

Although it is not well understood why brain cells are selectively damaged by methylmercury, one possible reason is that the mercury-protein complex persists for long period of time in the brain cells due to its particular composition and interfere with protein synthesis (Clarkson and Magos, 2006). These effects can cause a series of neurological symptoms and disorders including sensory problems and cognitive 
impairments, especially in children whose developing brain is particularly sensitive to mercury exposure. While children seem to be more sensitive to mercury, recent studies indicate that mercury exposures have serious adverse effects in adults as well. Study by Hyman (2004) has associated adult methyl mercury exposures to insomnia, walking/hearing/vision impairments, and a whole series of brain disorders such as autism, Alzheimer and Parkinson disease, and many other neurodegenerative diseases. The mechanisms of how mercury affects the nerve cells is still poorly understood and are the subject of active research.

\subsection{Management of Dental Amalgam Waste}

Mercury use in the U.S. and Oregon continues and its release to the environment from commercial and industrial sources is a risk to human health and environment. Efforts should be made to eliminate or substitute mercury with a less hazardous material that poses smaller risk to environmental and human health. When this is not possible due to economic, technological, or other reasons, the most important task is to control the release of these hazardous materials and properly manage the waste that are generated, by using hazardous materials.

There is a decreasing tendency in the use of amalgam in restorative dentistry due to technological advancements and the development of new, effective filling materials (Dental Amalgam Program Report 2015). The replacement of amalgam by other, less hazardous materials could reduce mercury releases. However, elemental mercury is a still a preferred material to restore cavities at many dental offices, despite 
of its known potential to cause damage to environment and human health. Dental amalgam is expected to be used in the future, therefore, it is important to regulate the management of the generated amalgam waste. With careful use and proper management the release of mercury from this source can be minimized and risks associated to dental mercury applications can be greatly reduced. In fact, among the industrial and commercial sources, dental offices are one of the best examples of how proper management can reduce mercury emission.

In recent years, dental amalgam has been an emerging regulatory concern and there are increasing efforts from regulatory agencies to better control dental offices' waste management practices. One main reason for this is that although dental clinics individually present small contributions to total mercury load, the large number of the dental clinics in different regions of the US, that altogether present a significant mercury release into municipal sewage systems (DEQ, 2006, Dental Amalgam Program Report, CWS, 2015).

These statistics have caused regulatory agencies to address dental offices' amalgam management. Recently, a series of changes happened involving dental offices amalgam waste managing procedures. Oregon Revised Statutes (ORS) came into effect in 2013, requiring implementing and maintaining the best management practices developed by the Oregon Dental Association, to prevent dental mercury from entering into wastewater, waterways, garbage, and the air (Oregon Amalgam Law ORS 679.520, $679.525,2013)$. This statute was significant for dental waste regulation and requiring 
the implementation of best management practices, previously only recommended for dental facilities which are now subject to inspections for compliance and enforcement.

One effective method to reduce the release of dental amalgam waste into the environment is capturing amalgam at the point of generation, in the dental clinics, and avoid release to the sewer system. As dental mercury is present in many dental clinics all over the world, it is a subject of many international studies (Baskhar, 2012, Jokstad et al., 2006, Trip, 2001, McManus, 2003). These studies agree that proper management and disposal of mercury-containing dental waste are key in preventing adverse impact, and that with proper management and separating equipment the release of mercury from dental offices can be greatly reduced.

The Oregon Amalgam Law specifies that dental offices shall install amalgam separators that remove at least $95 \%$ of the amalgam passing through the drain on which it is installed. The rule also requires maintaining an amalgam separator maintenance log that should be made available for inspections performed by the Oregon Board of Dentistry. Based on the Oregon Amalgam Law, at dental offices amalgam separators, complying with the ISO 11143 standard, need to be installed at a minimum. However, other amalgam capturing devices are also available and encouraged for use (American Dental Association), such as vacuum pump filters and chair side traps. Pump filters exist in wet and dry version and usually installed alternatively to amalgam separators, to capture larger amalgam particles before enter the sewage system. Chair side trap are disposable or reusable filters used in the chair side dental unit to trap coarse amalgam particles. While both filter pump and chair side 
traps help to capture waste amalgam, both apparatus captures the coarse portion of the amalgam, and approximately $40-60 \%$ of the total amalgam waste pass through these apparatus.

Ever since high efficiency amalgam separators have been available on the market, able to trap fine amalgam particles, those have been highly encouraged by federal and state dental associations and now those are required by law, in most states, including Oregon. EPA stated that requiring the installation of amalgam separators in dental offices, a great improvement can be achieved, with relatively less, and low-cost effort (an amalgam separator cost in average $\$ 700$, based on EPA estimates). As of 2014, twelve states have implemented mandatory programs to minimize dental mercury emissions, and many other states have proposed rules or had some kind of pretreatment programs (American Dental Association, 2014).

The 2015 Dental Program Report from Clean Water Services stated that the maintenance of amalgam capturing devices and amalgam waste management elements of the amalgam law are important. CWS inspected 284 dental offices, located in the CWS service district, they found that $78 \%$ of the offices were in-compliance with the rules which was significantly higher compared to the previous year. The inspections have shown that all dental office had amalgam separators installed. Main violations were: collecting waste amalgam together with biohazard waste or putting it into regular trash. In addition to the regular physical inspections, another important element of the CWS Dental Amalgam Program, that, in addition to the annual physical inspections, also requires regular self-monitored reports from the participating dental offices, in 
which they need to submit certificates of recycling and other records proving the proper maintenance of their amalgam capturing equipment. It is important that BMPs and regulations clearly communicate how different types of amalgam waste be collected and recycled (Table 1$)$.

\section{Table 1: Best Management Practices for Amalgam Waste}

\section{USE AMALGAM CAPTURING DEVICES}

- Chair side traps

- Vacuum pump systems

- Amalgam separators

\section{OTHER BEST MANAGEMENT PRACTICES}

- Eliminate/Reduce/Substitute amalgam fillings and use other, less hazardous filling materials whenever possible and appropriate

- Don't use bulk mercury; use pre-capsulated amalgam alloys

- Stock different sizes of amalgam capsules

- Use line cleaners that minimize dissolution of amalgam

- Properly manage amalgam-containing dental waste:

- Manage amalgam waste through recycling whenever possible

- Collect separately contact and non-contact amalgam waste

- Use proper, airtight containers

- Use proper labeling: "Contact/Non-contact Amalgam Waste for Recycling", "Amalgam Capsule Waste for Recycling", or as directed by the recycler

- $\quad$ Send used traps, filters, empty amalgam capsules to certified mercury recycler

- Don't put extracted teeth and other contact amalgam-containing waste into biohazard containers 
The Best Management Practices of the American Dental Association identify amalgam-containing waste types based on whether the waste was in contact with human bodily fluid or not. Based on the ADA guide, contact amalgam such as such as extracted teeth, scrap amalgam from old dental fillings should be collected separately from non-contact amalgam (which was not exposed to bodily fluid), in airtight, properly labeled, closed containers, and both these wastes should be sent back to a certified amalgam recycler. Vacuum pump filters, disposable chair side traps, and empty amalgam capsules can be collected together in wide-mouthed, airtight, containers, and should be sent back to an amalgam recycler as well.

The Best Management Practices by ADA also describe the amalgam capturing devices that should be used to trap amalgam particles before those would enter into the public sewage system (Table 2). The three devices used at dental offices are chair side traps, vacuum pump filters, and amalgam separators.

In most cases, used cartridges from amalgam separators can be sent back to the company from whom the separator was purchased. The Dental Hygiene Program of Mt. Hood Community College (MHCC, Gresham, OR) and many other dental offices in Oregon have been using the services of local company that developed a high quality recycling program for its customers (Dental Amalgam Program Report, 2015). Used cartridges can be shipped back to the company, using a safe containers, provided by the company. 
Table 2: Comparison of Dental Amalgam Capturing Devices

\begin{tabular}{|c|c|c|c|c|}
\hline $\begin{array}{c}\text { TYPE OF } \\
\text { AMALGAM } \\
\text { CAPTURING } \\
\text { DEVICE }\end{array}$ & DESCRIPTION & $\begin{array}{l}\text { REMOVAL } \\
\text { EFFICIENCY }\end{array}$ & ADVANTAGES & DISADVANTAGES \\
\hline $\begin{array}{l}\text { Chair side } \\
\text { traps }\end{array}$ & $\begin{array}{l}\text { Small } \\
\text { disposable or } \\
\text { reusable filters } \\
\text { in the chair side } \\
\text { unit to capture } \\
\text { dental } \\
\text { amalgam. }\end{array}$ & $\begin{array}{l}\text { - Usually traps } \\
\text { particles } \\
\text { greater than } \\
0.7 \mathrm{~mm} \text { in } \\
\text { diameter } \\
\text { - ADA: } 78 \% \\
\text { - CDA: } 40-60 \% \\
\text { - Other studies: } \\
\text { wide variation } \\
\text { (18-80\%) }\end{array}$ & $\begin{array}{l}\text { - Inexpensive } \\
\text { - Comes in reusable } \\
\text { and disposable } \\
\text { versions } \\
\text { - It can be cleaned by } \\
\text { personnel at the } \\
\text { dental clinics } \\
\text { - Easy to clean \& } \\
\text { replace } \\
\text { - No significant } \\
\text { operation \& } \\
\text { maintenance cost } \\
\end{array}$ & $\begin{array}{l}\text { - Removes mainly the } \\
\text { coarse particles } \\
\text { - Disposable traps } \\
\text { create waste } \\
\text { - Lower overall } \\
\text { removal efficiency }\end{array}$ \\
\hline $\begin{array}{l}\text { Vacuum pump } \\
\text { systems }\end{array}$ & $\begin{array}{l}\text { Amalgam } \\
\text { filtration } \\
\text { equipment to } \\
\text { capture dental } \\
\text { amalgam, to } \\
\text { prevent } \\
\text { amalgam } \\
\text { entering into } \\
\text { the public } \\
\text { sewage } \\
\text { system. They } \\
\text { can be wet or } \\
\text { dry filter } \\
\text { systems. } \\
\end{array}$ & $\begin{array}{l}\text { - Usually } \\
\text { captures } \\
\text { particles } \\
\text { greater than } \\
0.42 \mathrm{~mm} \text { in } \\
\text { diameter } \\
\text { - ADA: } 78 \% \\
\text { removal } \\
\text { efficiency } \\
\text { - CDA: } 40-60 \% \\
\text { removal } \\
\text { efficiency }\end{array}$ & $\begin{array}{l}\text { - Dry pump filter } \\
\text { systems do not } \\
\text { require filter and } \\
\text { water to run; those } \\
\text { are most cost- } \\
\text { effective and require } \\
\text { less maintenance }\end{array}$ & $\begin{array}{l}\text { - Less effective than } \\
\text { amalgam separators } \\
\text { - Pump filters need to } \\
\text { be changed at least } \\
\text { monthly or as } \\
\text { directed by the } \\
\text { manufacturer } \\
\text { - Wet systems are } \\
\text { loud and smelly } \\
\text { - Filter replacement } \\
\text { cost } \\
\text { - Maintenance time } \\
\text { - Filters must be sent } \\
\text { to mercury recycler }\end{array}$ \\
\hline $\begin{array}{l}\text { Amalgam } \\
\text { separators }\end{array}$ & $\begin{array}{l}\text { Devices } \\
\text { installed on the } \\
\text { vacuum lines of } \\
\text { dental offices } \\
\text { capturing } \\
\text { dental } \\
\text { amalgam to } \\
\text { prevent it from } \\
\text { entering the } \\
\text { public sewage } \\
\text { system. } \\
\text { In many states } \\
\text { it is required by } \\
\text { the law in } \\
\text { dental offices. } \\
\end{array}$ & $\begin{array}{l}\text { - Highest } \\
\text { efficiency } \\
\text { among the } \\
\text { amalgam } \\
\text { capturing } \\
\text { devices } \\
\text { - Certified to } \\
\text { remove at } \\
\text { least } 95 \% \text { of } \\
\text { the amalgam, } \\
\text { but many of } \\
\text { them have as } \\
\text { high as } 99.9 \\
\% \text { efficiency }\end{array}$ & $\begin{array}{l}\text { - Highest efficiency } \\
\text { among amalgam } \\
\text { capturing devices } \\
\text { - Manufacturer often } \\
\text { offer free or } \\
\text { affordable recycling } \\
\text { services for separator } \\
\text { cartridges } \\
\text { - It is one-time cost; } \\
\text { the amalgam } \\
\text { separator does not } \\
\text { need to be replaced, } \\
\text { only the cartridge }\end{array}$ & $\begin{array}{l}\text { - Compared to other } \\
\text { amalgam capturing } \\
\text { devices it relatively } \\
\text { costly }(\$ 160-\$ 2,000) \\
\text { - Installation \& } \\
\text { cartridge } \\
\text { replacement } \\
\text { requires skills } \\
\text { - It requires regular } \\
\text { maintenance } \\
\text { - There is an ongoing } \\
\text { maintenance cost } \\
\text { - Due to its size, it } \\
\text { requires more space } \\
\text { to install } \\
\end{array}$ \\
\hline
\end{tabular}

Sources: Burkhart Dental, University of Massachusetts, California Dental Association, Oral Health 
Chair side traps are inexpensive filters (Figure 5) in chair side units that can trap the coarse portion of dental amalgam. Many dental offices, including the MHCC Dental School have been using disposable traps, to reduce mercury releases. These traps are emptied and cleaned on a regular base and then reused. Cleaning schedule of chair side traps and replacement for amalgam separator cartridges are largely dependent on the types of the services that dentists provide and also, the number of patients they treat. A dental school like the MHCC Dental Hygiene Department where mostly education happens generate significantly less amalgam waste than an established dentistry with a busy schedule; therefore the maintenance schedule may be very different of these dental facilities.
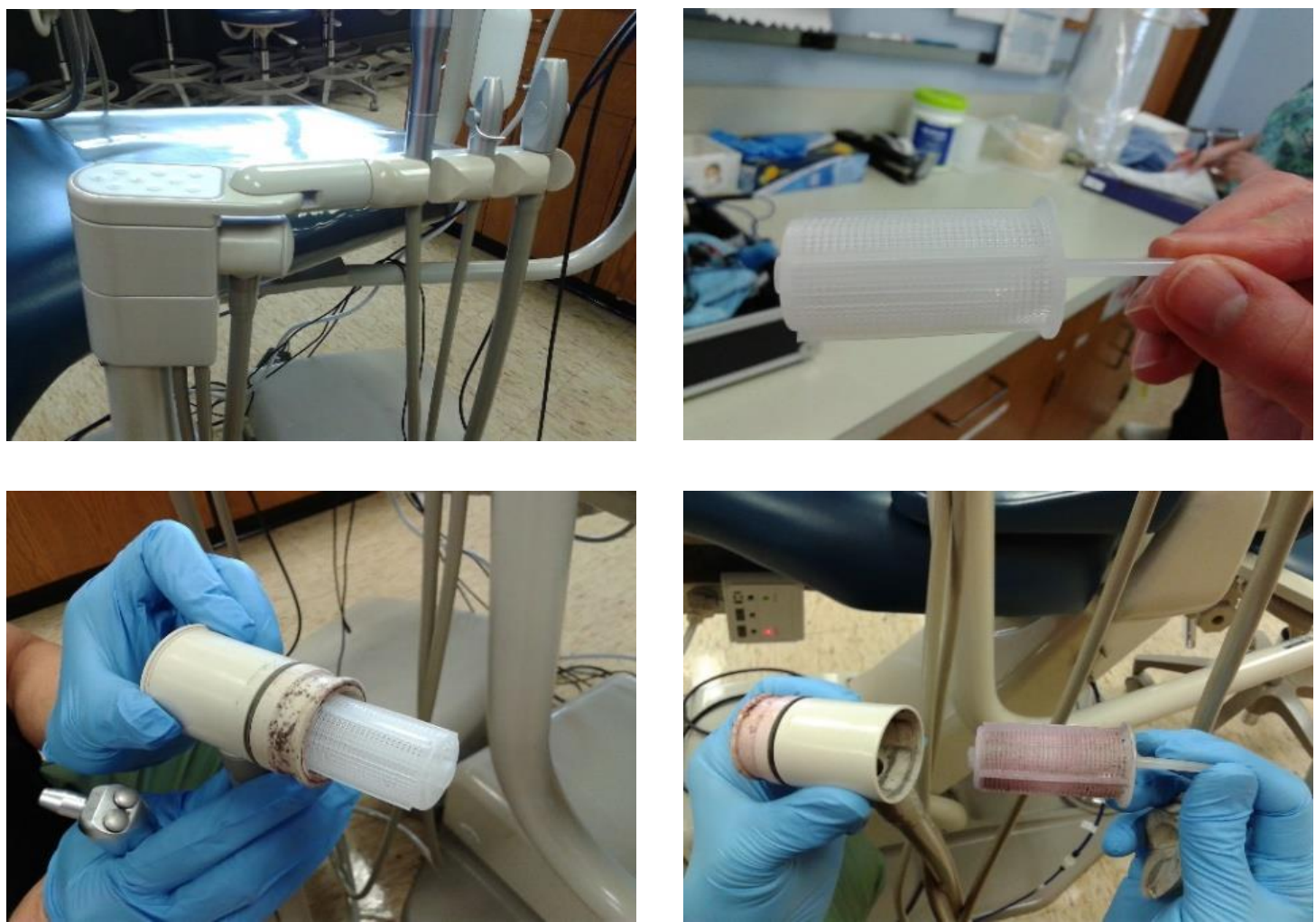

Figure 5: Clean and mercury-contaminated chair side traps

Source: Marta Szabatin, MHCC Dental Department, 2016 
There are many studies available investigating and estimating the amalgam use and waste generation of dental offices. The most often used one is conducted by Vandeven \& McGinnis (2005), estimated that in average, approximately $340 \mathrm{mg}$ of mercury is used for each amalgam filling, and about $9 \%$ of this amount is discharged into the suction system. Due to mercury loss from the typical lifespan of an amalgam filling, by the time of the removal of the filling, there is about $280 \mathrm{mg}$ of mercury present, $90 \%$ of which ends up in the suction system. Using these estimations and their own data on the number of patients and treatment types, dental clinics can get an idea how much mercury waste is generated at their facilities. Furthermore, using the removal efficiency of the different amalgam capturing devices, the amount of the mercury released into the sewage system can be estimated.

The Clean Water Services Dental Amalgam Program Report (2014) showed that in a single year, a significant improvement was achieved at many areas; by 2014 , all dental clinics had amalgam separator installed, the number of non-compliant dental clinics has decreased (by approx. $41 \%$ ), the number of dentists who do not place amalgam fillings has also decreased by (by approx. $1.2 \%$ ). These improvements all contributed to the reduction of mercury emission from dental clinics. The statistics based on the annual inspections has shown that just the amalgam separators themselves resulted in approximately 19 lbs less mercury discharge to the waste water treatment facilities in the CWS service district. 
In addition to high quality amalgam capturing devices, proper amalgam waste management techniques are also of key importance. As the ADA Best Management Practices instructs, no dental amalgam waste should be collected together with biohazard waste. During incineration of the biohazard waste, mercury found in the dental amalgam waste evaporates and get released into the air. Once in the air, mercury vapors enter the mercury cycle, get deposited on land and waterbodies, then will be taken up by organisms and can cause serious harms.

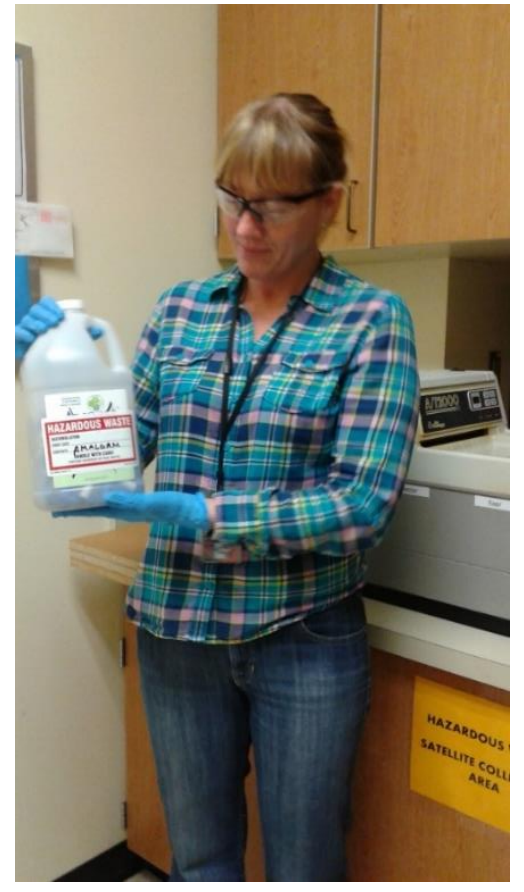

Amalgam containing dental waste, including empty capsules, should be collected in separate, well-sealed containers (Figure 7) and sent to certified amalgam recyclers. It is also important to make sure that dental students do not take home or throw away the artificial teeth used for practicing dental fillings. Those items should be also collected with non-contact amalgam, until it is recycled.

Figure 7. Handling empty amalgam capsules

at MHCC Dental Hygiene Department

Source: Marta Szabatin, 2016

Another issue can be to find a recycling solution at an affordable price. The amalgam recycling options in Oregon are very limited and even using the state contract quotes, dental schools with limited hazardous waste budget such as Mt. Hood Community College may encounter difficulties to find a good recycling solution. 


\section{CONCLUSIONS}

Studies conducted in the Tualatin Basin have shown that the efforts to implement BMPs at dental offices appear to be having an effect by reducing mercury from dentist offices being released to sewer systems and POTWs and mercury influent concentrations to POTWs showing a decreasing trend in the last decade (CWS, Mercury Minimization Plan, 2015). The Willamette Mercury TMDL, the Oregon Amalgam Law, and in general more effective control of mercury discharges from industrial and commercial sources through the NPDES system and Mercury Minimization Plans have had a role in these improvements. Best management practices (BMPs), recommended by professional entities such as the American and Oregon Dental Association are effective in providing dental clinics and schools with reliable and easily accessible information on how to manage mercury-containing dental materials.

Best management practices (BMPs) that provide guidance on how to achieve a high quality, environmentally responsible management of dental waste are important tools for dental schools and clinics. In addition to BMPs, regulations are key to these facilities to develop, implement, and maintain their dental amalgam management programs. The progress in regulatory tools has been significant but more efforts are needed, to further reduce mercury emissions. The EPA proposed rule is intended to fill this gap in the future. The EPA rule would the installation of amalgam separators that have at least $99 \%$ removal efficiency (current is $95 \%$ in Oregon), it would require a baseline reporting, and it would put non-compliant dental offices into a so-called 
"Significant Industrial User" status that means more frequent inspections, and more reporting requirements towards the POTWs to whom the dental office discharges.

The mercury release of these facilities can be reduced significantly with relatively small efforts: developing and implementing mercury minimizations programs, using efficient mercury trapping technologies, and proper waste disposal methods. Regulatory efforts have recently been initiated to re-evaluate dental clinics in terms of mercury emission and possibly categorize them as Significant Industrial Users (CWS Dental Amalgam Program Report, 2014. This would impose additional requirements to dental clinics and schools, and would ensure that mercury minimization efforts and regulatory compliance are met. Education, outreach, awareness and regulation are important to successfully address the issue of mercury emissions from dental facilities. With the installation and proper maintenance of amalgam capturing apparatus, and appropriate management of amalgam waste, mercury emissions form dental offices can be greatly reduced. Clear guidelines and regulations, and safe, accessible, and affordable mercury recycling options are critical to achieve an environmentally responsible, high quality dental waste management which in turn, will help to reduce environmental mercury and risks to human and environmental health. 


\section{REFERENCES}

Akoto, O., Eshun, F.B., Darko, G., Adei, E. (2014). Concentrations and Health Risk Assessments of Heavy Metals in Fish from the Fosu Lagoon. International Journal of Environmental Research. 8(2): 403-410

American Dental Association. Best Management Practices for Dental Waste. (2007).

Retrieved from

http://www.ada.org/ /media/ADA/Member\%20Center/Flles/topics amalgamwast e brochure.ashx on May 19, 2016

American Dental Association. (2009). Statement of dental amalgam. Retrieved from http://www.ada.org/en/about-the-ada/ada-positions-policies-andstatements/statement-on-dental-amalgam on May, 20, 2016

Azavedo, R., Rodriguez, E. (2012). Phytotoxicity of Mercury in Plants: A Review. Journal of Botany. Volume 2012 (2012), Article ID 848614. http://dx.doi.org/10.1155/2012/848614

Atwell, L., Hobson, K.A., Welch, H.A. 1998. Biomagnification and bioaccumulation of mercury in an Arctic marine food web: Insights from stable nitrogen isotope analysis. Canadian Journal of Fisheries and Aquatic Sciences 55(5):1114-1121

Baghele, O. N., et al. (2013). A simplified model for biomedical waste management in dental practices - A pilot project at Thane, India. European Journal of General Dentistry. 2(3): 235-240

Batrakova, N., Travnikov, O., Rozovskya, O. (2014). Chemical and physical transformations of mercury in the ocean: a review. Ocean Science, 10: 10471063

Boening, D.W. (2000).Ecological effects, transport, and fate of mercury: a general review. Chemosphere, Volume 40, Issue 12, June 2000, Pages 1335-1351

Boszke, L., Kowalski, A., Glosinska, G., Szarek, R., Siepak, J. (2002). Environmental factors affecting speciation of mercury in the bottom sediments; an overview. Polish Journal of Environmental Studies. 12(1): 5-13 
Brumbaugh, W.G., Krabbenhoft, D.P., Helsel, D.R., Wiener, J.G. (2000). A National study of mercury contamination of aquatic ecosystems along multiple gradients: Bioaccumulation in fishes. Conference paper presented at the 21th annual meeting of the Society of environmental Toxicology and Chemistry (SETAC), Nashville, TN, Nov 12-16, 2000. Retrieved from http://groups.northwestern.edu/nur/files/articles/full/Ji.pdf on May 20, 2016

Burkhart Dental.2012. Protect your success. U.S. EPA due to issue proposed dental rule. Provided by Solmetex. Catalyst Magazine Issue 1. Retrieved from http://www.burkhartdental.com/sites/default/files/EPA.pdf on June 8, 2016

Caldwell, C. (CWS). (2014). Dental Amalgam Program Report 2014.

California Dental Association. 2013. Amalgam Waste Best Management Practices. Retrieved from http://www.cda.org/Portals/0/pdfs/practice support/Amalgam Waste Best Practi ces.pdf on June 9, 2016

Chin, G., Chong, J., Kluczewska, A., Gorjy, S., Tennant, M. (2000). The environmental effects of dental amalgam. Australian Dental Journal. (45)4: 246-249

Clarkson, T.W., Magos, L. (2006). The toxicology of mercury and its chemical compounds. Critical Reviews in Toxicology. 36(8): 609-62

Clean Water Services Dental Amalgam Program Report, Draft, 2014.

Clean Water Services. Mercury Minimization Plan. 2015.

Condrin, A. K. (2004). The use of CDA best management practices and amalgam separators to improve the management of dental wastewater. Journal of the California Dental Association. 32(7): 583-92

Compeau, G.C., Bartha, R. (1985). Sulfate-reducing bacteria: principal methylators of mercury in anoxic estuarine sediment. Applied Environmental Microbiolgy. 50(2):498-502 
Davidson, P.W., Myers, G.J., Weiss, B. (2006). Mercury exposure and child development outcomes. Pediatrics. 113(4 Suppl): 1023-1029

Dietz, R., Sonne, C., Basu, N., Braune, B., O'Hara, T. (2013). What are the toxicological effects of mercury in Arctic biota? Science of the Total Environment. 443(213): $775-790$

Drummond, J. L., Cailas, M. D., Croke, K. (2003). Mercury generation potential from dental waste amalgam. Journal of Dentistry. 31(7): 493-501

Hiltz, M. (2007). The environmental impacts of dentistry. Journal of the Canadian Dental Association. (73)1: 59-62

Hoekstra, A.Y., Wiedmann, T.O. (2014). Humanity's unsustainable environmental footprint. Science. 344 (6188): 1114-1117

Hope, B.K. (2005). An assessment of anthropogenic source impacts on mercury cycling in the Willamette Basin, Oregon, USA. Science of the Total Environment. 356(2006): 165-191

Hope, B. K., Rubin, J.R. (2005). Mercury levels and relationships in water, sediment, and fish tissue in the Willamette Basin, Oregon. Archives of Environmental Contamination and Toxicology. 48(3): 367-380

Hyman, M. H. (2004). The impact of mercury on human health and the environment. Journal of Alternative Therapies in Health and Medicine. Jokstad, A., Fan, P. L. (2010). Amalgam Waste management. International Dental Journal. 56(3): 147153

Jackson, A.K., Eversm D.C., Folsom, S.B., Condon, A.M., Diener, J., Goodrick, L.F., McGann, A.J., Schmerfeld, J. (2011). Mercury exposure in terrestrial birds far downstream of an historical point source. Environmental Pollution. 159(12): 3302-3308

Ji, I. (2011). The bioavailability of mercury in aquatic systems. Dissertation. Retrieved from http://groups.northwestern.edu/nurj/files/articles/full/Ji.pdf on May 15, 2016 
Lindqvist, O., Rodhe, H. (1985). Atmospheric mercury-a review. Wiley Online Library, Earth Sciences, Meteorology. 37B(3): 136-159

McManus, K. R., Fan, P. L. (2003). Purchasing, installing and operating dental amalgam separators: practical issues. American Dental Association. 134(8): 1054-1065

Nordberg, G.F., Fowler, B.A., Nordberg, M., Friberg, L.T. (2015). Handbook on the toxicology of metals, Volume I General considerations, $4^{\text {th }}$ Ed. Elsevier

Oral Health. 2011. A buyer's guide to dental vacuum systems. Retrieved from http://www.oralhealthgroup.com/features/a-buyers-guide-to-dental-vacuumsystems/ on June 8, 2016

Oregon Department of Environmental Quality. (2006). Willamette Basin Mercury TMDL. Retrieved from http://www.deq.state.or.us/wq/tmdls/docs/willamettebasin/willamette/chpt3mercur y.pdf on May 11, 2016

Oregon Health Authority. (2016). OHA issues statewide advisory recommending limited bass consumption. Oregon Health Authority News and Information. Retrieved from http://www.oregon.gov/oha/news/Pages/OHA\%20issues\%20statewide \%20advisory\%20recommending\%20limited\%20bass\%20consumption.aspx on May 20, 2016

Park, J.G., Curtis, L.R. (1997). Mercury distribution in sediments and bioaccumulation by fish in two Oregon reservoirs: Point-source and non-point source impacted systems. Archives of Environmental Contamination and Toxicology 28: 61-68

Pellow, D.N., Nyseth Brehm, H. (2013). An Environmental Sociology for the TwentyFirst Century. Annual Review of Sociology. 39:229-250

Rathore, M., Singh, A., Pant, V.A. (2012).The dental amalgam toxicity fear: A myth or actuality. Toxicology International. 19(2): 81-88

Renzoni, A., Zino, F., Franchi, E. (1997). Mercury levels along the food chain and risk for exposed populations. Environmental Research. Section A 77: 68-72 
Sackett, D.K., Cope, W.G., Rice, J.A., Aday, D.D. (2013). The Influence of Fish Length on Tissue Mercury Dynamics: Implications for Natural Resource Management and Human Health Risk. International Journal of Environmental Research and Public Health. 10(2): 638-659

Scheuhammer, A.M., Meyer, M.W., Sandheinrich, M.B., Murray, M.W. (2007). Effects of Environmental Methylmercury on the Health of Wild Birds, Mammals, and Fish. AMBIO: A Journal of the Human Environment. 3691): 12-19

Singh, R.D., Jurel, S.K., Tripathi, S., Agrawal, K.K., Kumari, R. (2014). Mercury and other biomedical waste management practices among dental practitioners in India. BioMed Research International, Article ID 272750, 6 pages, 2014. doi:10.1155/2014/272750

Sunderland, E.M., Selin, N.E. (2012). Future trends in environmental mercury concentrations: implications for prevention strategies. Environmental Health. 12:2

Tchounwou, P. B., Yedjou, C. G., Patlolla, A. K., \& Sutton, D. J. (2012). Heavy Metals Toxicity and the Environment. EXS, 101, 133-164. http://doi.org/10.1007/978-3$\underline{7643-8340-4 \quad 6}$

Tong, Z. (2012). Mechanisms of microbial formation and photo-degradation of methylmercury in the aquatic environment. Dissertation. Retrieved from Duke University Libraries http://dukespace.lib.duke.edu/dspace/handle/10161/5569 from on May 19, 2016

United Nations Environment Programme UNEP (2013). Global Mercury Assessment 2013: Sources, Emissions, Releases and Environmental Transport. UNEP Chemicals Branch, Geneva, Switzerland

University of Massachusetts, Massachusetts Dental Society, American Dental Association, Executive Office of Environmental Affairs, Department of Environmental Protection, Massachusetts Water Resources Authority. 2003. Development, Evaluation and Implementation of a Testing Protocol for Evaluation of Technologies for Removal of Mercury from Dental Facilities: Part I - Field Studies and Protocol Evaluation June 2003. Retrieved from 
http://www.mass.gov/eea/docs/eea/step/mercury-remove-dental-part1.pdf on June, 82016

US Environmental Protection Agency. (2016). EPA Dental Effluent guidelines. Retrieved from https://www.epa.gov/eg/dental-effluent-guidelines on May 19, 2016

US Environmental Protection Agency. (2016). Health effects of exposure to mercury. Retrieved from https://www.epa.gov/mercury/health-effects-exposures-mercury on May 18, 2016

US Food and Drug Administration. 2014. What You Need to Know About Mercury in Fish and Shellfish (Brochure). Retrieved from http://www.fda.gov/food/resourcesforyou/consumers/ucm110591.htm on May 18, 2016

Van Assche, F., Clijsters, H. (1990). Effects of metals on enzyme activity in plants. 13(3): 195-206

Vandeven, J.A., McGinnis, S.L. 2005. An assessment of mercury in the form of amalgam in dental wastewater in the United States. Water Air and Soil Pollution. 164(1): 349-366

Varian-Ramos, C.W., Swaddle, J.P., Cristol, D.A., (2014). Mercury reduces avian reproductive success and imposes selection: an experimental study with adult or lifetime - exposure in zebra finch. Public Library of Science. 9(4): e95674

Watras, C.J., Huckabee, J.W. 1994. Mercury Pollution, Integration and Synthesis. CRC Press

Mol, J.H., Ramlal, J.S., Lietar, C., Verloo, M. 2001. Mercury contamination in freshwater, estuarine, and marine fished in relation to small-scale gold mining in Suriname, South America. Environmental Research. 86(2): 183-197

Yaginuma-Sakuray, K., Murata, K., Iwai-Shimada, M., Nakai, K., Kurokawa, N., Tatsuta, $\mathrm{N}$, Satoh, H., 2012. Hair-to-blood ratio and biological half-life of mercury: experimental study of methylmercury exposure through fish consumption in humans. The Journal of Toxicological Sciences. 37(1): 123-130 